\title{
Physiological energetics of mussel larvae (Mytilus edulis). III. Respiration
}

\author{
Martin Sprung* \\ Biologische Anstalt Helgoland, Meeresstation, D-2192 Helgoland, Federal Republic of Germany
}

\begin{abstract}
Respiration rates of Mytilus edulis L. eggs, trochophore and veliconcha larvae of different sizes have been estimated at 6,12 and $18^{\circ} \mathrm{C}$. They were related to data of body weight and filtration capacity. Maximum swimming speeds observed corresponded to the velocity with which the larva sinks. The significance of activity could thus be discussed regarding the sinking rates of the larva; expressed as percentage of the respiration rate it was highest at low temperatures and increased with larval size.
\end{abstract}

\section{INTRODUCTION}

Measurement of oxygen consumption is assumed to provide a reasonable estimate of metabolic heat loss of mussel larvae. These small organisms, however, require a special measuring procedure. Polarographic and volumetric methods fitted for this purpose (e.g. Cartesian and gradient diver) have been tested successfully (Zeuthen, 1947; Davenport, 1976; Riisgård et al., 1981).

Like most bivalve larvae, mussel veliconcha are capable of actively regulating their position in the water column. They do this by means of cilia, which are situated on a velum, and which effect feeding at the same time (Strathmann et al., 1972). The speed of vertical migration of various species has been reported as being about 0.5 to $7 \mathrm{~mm} \mathrm{~s}^{-1}$ (Isham and Tierney, 1953; Turner and George, 1955; Konstantinova, 1966; Wood and Hargis, 1971; Cragg and Gruffydd, 1975; Hidu and Haskin, 1978; Cragg, 1980; Mann and Wolf, 1983).

Trochophores and early veligers generally swim continuously and tend to accumulate at the water surface. After some days, together with the formation of a shell, pauses in ciliary beating occur: they alternately sink and swim up in a vertically orientated spiral. This swimming pattern has been described for various

- Present address: Physiological Ecology Section, Department of Zoology, University of Köln, Weyertal 119, D-5000 Köln 41, Federal Republic of Germany species of bivalve larvae: e.g. Mytilus edulis (Bayne, 1964), Ostrea edulis (Cragg and Gruffydd, 1975), Pecten maximus (Cragg, 1980) and Arctica islandica (Mann and Wolf, 1983).

It must be assumed that a great part of the metabolic energy is lost by activity; Zeuthen (1947) has calculated that it may contribute to 8 to $50 \%$ of the respiration of a mussel larva.

Here, next to respiration rates, estimates on the energy inherent in larval movement are presented. This is the third paper in a series of 4 in which important components of the energy budget of mussel larvae are described.

\section{MATERIALS AND METHODS}

\section{Measurement of respiration rates}

Respiration rates have been estimated in a gradient diver with laboratory-reared larvae. The rearing procedure has been described by Sprung (1984a).

The experimental setup of the gradient diver was only slightly different from that of Nexø et al. (1972). The salt gradient was built up in a $500 \mathrm{ml}$ graduated cylinder with $\mathrm{Na}_{2} \mathrm{SO}_{4}$ (density: 1.00 to $1.06 \mathrm{mg} \mathrm{mm}^{-3}$ ). Usually the divers had a gas volume of 3 to $6 \mu$ l (span: 2 to $12 \mu \mathrm{l}$ ). They were charged with 2 (large mussels) to 100 (small) larvae in order to effect a distinct migration within $1 \mathrm{~d}$. After an adaptation of at least $30 \mathrm{~min}$, its position in the gradient was recorded by eye every few 
hours. For one diver one data point has been estimated from a linear regression of its position (corrected by a control diver) versus time.

Measurements were conducted in temperature-constant rooms. Normally experimental and rearing temperature were identical. In case it differed, the larvae were adapted to the experimental temperature for $5 \mathrm{~d}$. A special situation was given for the eggs and trochophores. The adults had been kept at about $8^{\circ} \mathrm{C}$. In order to effect spawning, they were transferred individually into Erlenmeyer flasks. The flasks were filled with water of $18^{\circ} \mathrm{C}$ and brought into a $12^{\circ} \mathrm{C}$ room. At $6^{\circ} \mathrm{C}$ the measuring procedure started $5 \mathrm{~h}$ after release, the trochophores were $2 \mathrm{~d}$ old. At 12 and $18^{\circ} \mathrm{C}$ measuring procedure started directly after release of the eggs, the trochophores were $1 \mathrm{~d}$ old.

The larvae were fed with an Isochrysis culture directly before they were brought into the diver or they had starved for $1 \mathrm{~d}$. Within the process of evaluation, the volume of oxygen consumed was corrected to stan dard conditions. For transformation to energy units, $1 \mathrm{ml} \mathrm{O}_{2}$ was taken as 20.1 Joule (Crisp, 1971).

\section{Estimation of energy inherent in movement}

The energy inherent in larval movement was estimated by the sinking rate. In this particular situation, the larva is drawn through the water by a defined force $F$. It is the difference between the gravity pull $G$ and the buoyancy in seawater $B$ :

$$
F=G-B
$$

The force $F$ is necessary to overcome the friction of the water.

Gravity pull $\mathrm{G}$ was estimated from larval wet weight $W_{\text {larva }}$ (Sprung, 1984b) and gravity g. Buoyancy B was estimated from larval volume, the density of seawater $\varrho_{\text {seawater }}$ and gravity $g$. Density of the seawater $\varrho_{\text {seawater }}$ was checked by an araeometer. Salinity ranged between 29.7 and $33.3 \%$. The volume of the larva was estimated separately for the shell and the soft part multiplying its wet weight $\left(\mathrm{WW}_{\text {ussue }}\right.$ resp. $\left.\mathrm{W}_{\text {shell }}\right)$ with an estimate of its density $\varrho$. For the tissue, the density was assumed as $\varrho_{\mathrm{t} \text { ssue }}=1.3 \times 10^{-3} \mathrm{~kg} \mathrm{~m}^{-3}$. It was calculated for an egg of $77.8 \mu \mathrm{m}$ diameter with a wet weight of $323 \mathrm{ng}$ (Sprung, 1984b). For the shell a density of $\varrho_{\text {shell }}=2.5 \times 10^{-3} \mathrm{~kg} \mathrm{~m} \mathrm{~m}^{-3}$ was assumed according to the density of shells of adult mussels (Sprung, 1980).

$F=\left(W W_{\text {larva }}-\left(\frac{W W_{\text {tissue }}}{\varrho_{\text {ussue }}}+\frac{W W_{\text {shell }}}{\varrho_{\text {shell }}}\right) \times \varrho_{\text {seawaler }}\right) \times g$

The sinking rate was followed in a glass tube of $1.3 \mathrm{~cm}$ diameter with a stopwatch over a distinct distance. For one point, the arithmetic mean of 5 to 17 measurements was formed. Experiments were conducted in temperature-constant rooms. The larvae were killed with formalin just before the measurements.

\section{RESULTS}

Respiration rates have been represented graphically in Fig. 1. Rates measured directly after feeding and after $1 \mathrm{~d}$ of starvation did not differ significantly. They

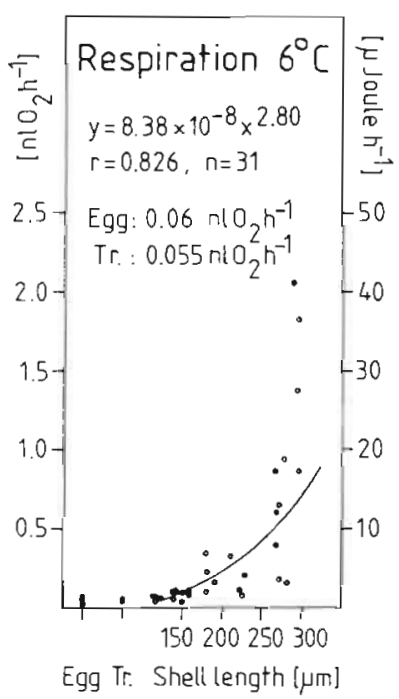

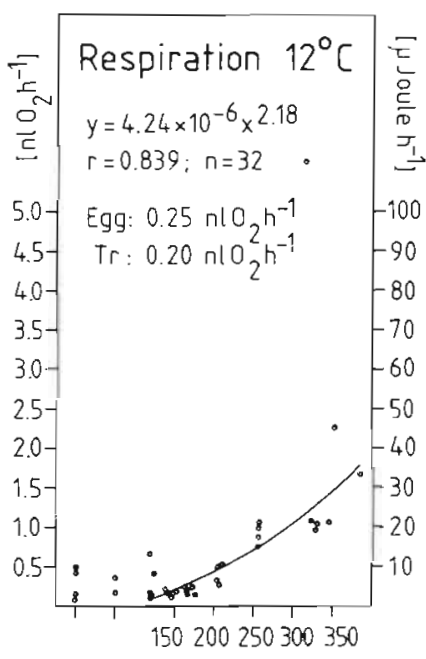

Egg Tr. Shell length $[\mu \mathrm{m}]$

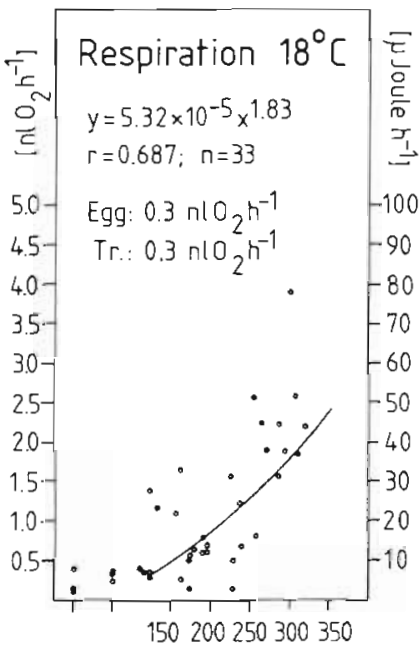

Egg Tr. Shell length $[\mu m]$

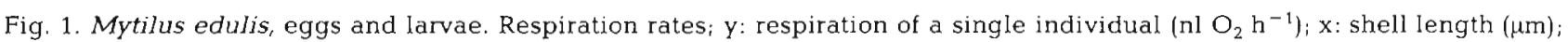
$\mathrm{r}$ : correlation coefficient; $\mathrm{n}$ : number of data points; mean respiration of an egg and a trochophore (tr.); conversion: $1 \mathrm{ml} \mathrm{O}_{2}=$ 20.1 Joule 
were thus pooled. Rates are plotted against the arithmetic mean of larval shell length in the diver. Fit and mean respiration of eggs and trochophores are also indicated.

Sinking rates recorded are presented in Fig. 2. Data points have been fitted as a function of shell length.

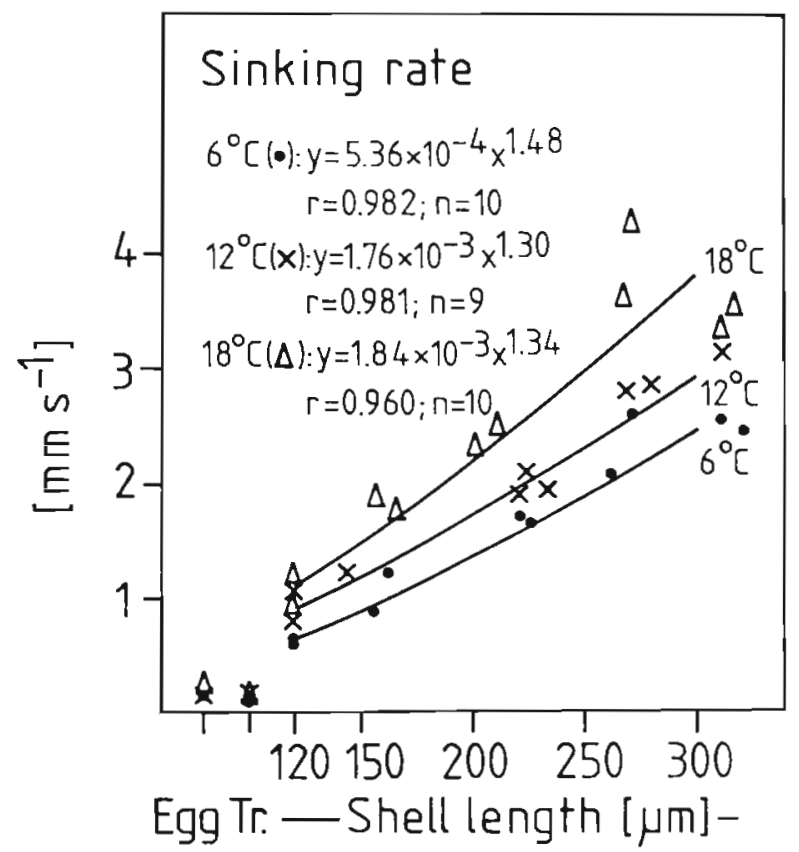

Fig. 2. Mytilus edulis, eggs and larvae. Sinking rates at 6,12 and $18^{\circ} \mathrm{C}$; $\mathrm{y}$ : sinking rates $\left(\mathrm{mm} \mathrm{s}^{-1}\right) ; \mathrm{x}$ : shell length $(\mu \mathrm{m})$; $\mathrm{r}$ : correlation coefficient; $\mathrm{n}$ : number of data points; one point represents the mean of 5-17 observations; tr.: trochophore

For calculation of the energy inherent in movement, it was assumed that the larva would swim in a horizontal direction with a velocity corresponding to the sinking rate. Table 1 demonstrates that this is a realistic assumption. These velocities have been recorded with a stopwatch under a dissecting microscope at the temperatures indicated. The capacity of the movement has been calculated from the product of sinking rate and force $\mathrm{F}$ described under 'Materials and Methods'. This value was doubled according to the assumption made above: one component serves to compensate sinking, the other to move the larva in the horizontal

Table 1. Mytilus edulis, larvae. Maximum recorded horizontal swimming velocities

\begin{tabular}{|ccc|}
\hline $\begin{array}{c}\text { Temperature } \\
\left({ }^{\circ} \mathrm{C}\right)\end{array}$ & $\begin{array}{c}\text { Shell length } \\
(\mu \mathrm{m})(\overline{\mathrm{x}} \pm \mathrm{sx})\end{array}$ & $\begin{array}{c}\text { Swimming velocity } \\
\left(\mathrm{mm} \mathrm{s}^{-1}\right)\end{array}$ \\
\hline 6 & $261 \pm 23$ & 1.25 \\
12 & $226 \pm 27$ & 2.00 \\
18 & $245 \pm 29$ & 3.30 \\
\hline
\end{tabular}

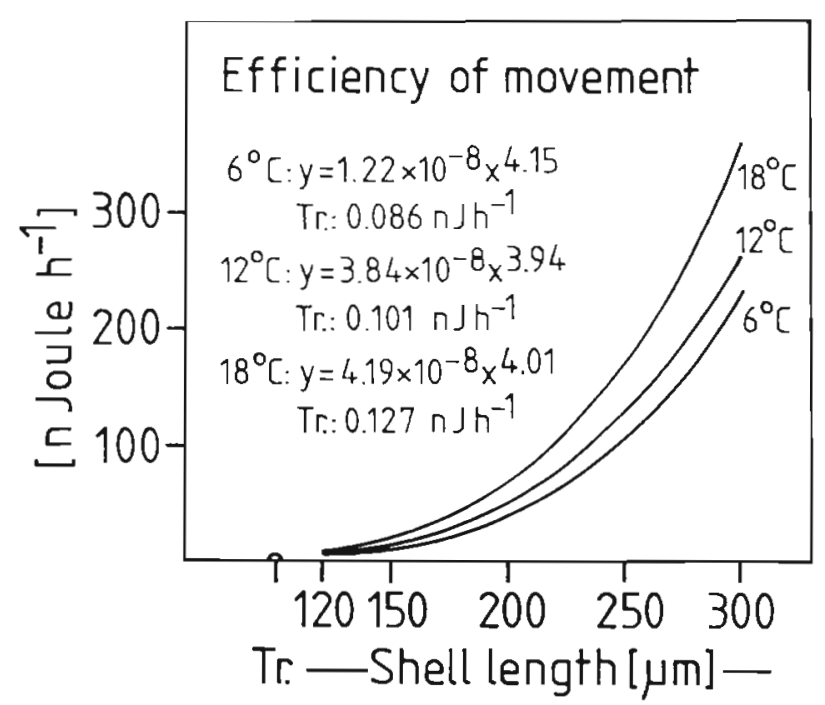

Fig. 3. Mytilus edulis, larvae. Efficiency of swimming in a horizontal direction with a speed corresponding to the sinking rate; calculated from the sinking rate (Fig. 2) and weight data (Sprung, 1984a); $y$ : efficiency (nJoule $\mathrm{h}^{-1}$ ); $\mathrm{x}$ : shell length $(\mu \mathrm{m})$

direction. This efficiency has been graphically represented in Fig. 3. It is markedly higher with the veliconcha than with the trochophore. Due to the higher sinking rate, the efficiency increases with larval size and temperature.

With respect to the temperature, this trend is just reversed when referring the efficiency to the respiration rates of the veliconcha (Fig. 1). However, it still increases with larval size (Fig. 4).

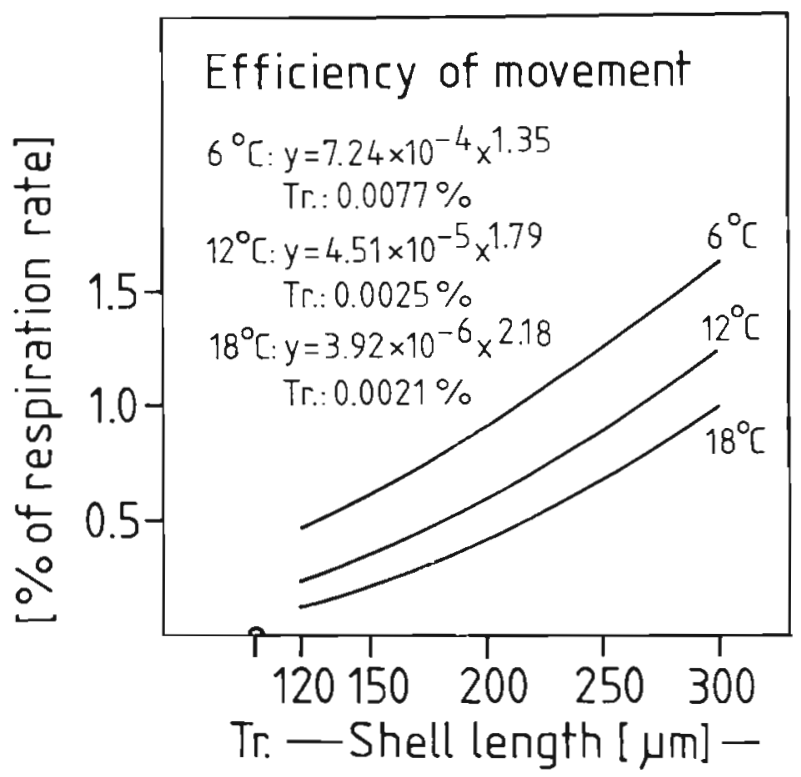

Fig. 4. Mytilus edulis, larvae. Efficiency of swimming as percentage of the respiration (calculated from Fig. 1 and 3); $y$ : efficiency of swimming (\% of the respiration); $x$ : shell length $(\mu \mathrm{m})$ 


\section{DISCUSSION}

Like the other variables of the energy budget investigated before, respiration is dependent (directly or indirectly) on many factors. They have been compiled and discussed by Zeuthen (1947) in general. Here only the important ones in this context will be considered.

\section{Respiration and temperature}

Table 2 lists the $Q_{10}$ values. Especially for eggs and trochophores they are difficult to interpret. This is due a great deal to the imperfect temperature adaptation caused by the thermal spawning stimulus. For the shelled larvae, the $\mathrm{Q}_{10}$-values between 6 and $12^{\circ} \mathrm{C}$ and between 12 and $18^{\circ} \mathrm{C}$ are very similar. This is in contrast to the temperature influence on growth and food uptake which levels off between 12 and $18^{\circ} \mathrm{C}$ (Sprung, $1984 \mathrm{a}, \mathrm{b}$ ). This indicates that Mytilus edulis larvae approach their maximum tolerable temperature limit. It lies at about $25^{\circ} \mathrm{C}$ (Hrs-Brenko and Calabrese, 1969; Lough, 1974).

\section{Respiration and activity}

Applying a quite different method, Vlymen (1970) obtained similar results as calculated here for copepods: he estimated the energy inherent in motion as 0.1 to $0.3 \%$ of the registered respiration. However, Klyashtorin and Yarzhombek (1973) argued that it is wrong to conclude that activity has consequently hardly any effect on respiration. Metabolic effort is only converted to the energy of the moving body with a certain efficiency. This concerns the transformation of chemical energy (as ATP) to the beats of the appendages (or cilia) and the transformation of this energy to the surrounding water. For the metabolic effort one must assume a value which can be 20 times higher than the energy inherent in motion. Consequently, the estimations presented here, do not contradict Zeuthen's (1947) calculation. Attention should be thus drawn to the trends rather than to the absolute values.
If swimming speed and sinking rate are also correlated in early larval stages, activity is more expensive for the veliconcha than for the trochophore (Fig. 3). This would make sense, because for the trochophore activity serves only in regulating the position of the larva. For the veliconcha, in contrast, swimming runs parallel with the process of food uptake.

Assuming that the graphs calculated in Fig. 1 are valid for a similar state of activity, it turns out that the larva has to spend a greater part of its metabolic activity for swimming with increasing size, especially at low temperatures (Fig. 4). This may have consequences for growth. Possibly the sigmoidal growth curves at $6^{\circ} \mathrm{C}$ (Sprung, 1984a) can be attributed to this finding.

Activity is one sore point in nearly all estimations of the respiration rate of bivalve larvae. In order to effect a measurable rate within a reasonable time, the larvae have to be highly concentrated.

This influences motility and may explain a good deal of the variability of these estimations. Walne (1966) and Millar and Scott (1967) observed reduced respiration rates with increasing concentration of oyster larvae. In contrast, Zeiss (1963) found an elevated oxygen consumption with daphnids at high concentrations. Despite this fact and different methods employed, respiration rates reported in the literature generally agree (Table 3 ).

\section{Respiration and nutrition}

Digestive processes cause an elevated metabolism in many organisms. This phenomenon is called specific dynamic action. It has been documented also for adult mussels (Bayne and Scullard, 1977). It was originally intended to have it included in the respiration rate when measuring directly after feeding and to exclude it when the larva had starved for one day. Obviously either the specific dynamic action lay below the accuracy of the method or it took only some 1 to $2 \mathrm{~h}$ and was thus much shorter than the whole measuring procedure. The latter hypothesis would be supported by data on the digestion of gastropod larvae (Pechenik and Fisher, 1979).

Table 2. Mytilus edulis. Temperature dependence of the respiration of eggs, trochophores and larvae of different shell lengths (calculated from Fig. 1)

\begin{tabular}{|ccccccccc}
\hline $\begin{array}{c}\text { Temperature } \\
\text { range }\end{array}$ & \multicolumn{5}{c}{$Q_{10}$-values } \\
& Egg & Trochophore & $120 \mu \mathrm{m}$ & $150 \mu \mathrm{m}$ & $200 \mu \mathrm{m}$ & $250 \mu \mathrm{m}$ & $300 \mu \mathrm{m}$ \\
\hline $6-12^{\circ} \mathrm{C}$ & 10.8 & 8.6 & 5.3 & 3.7 & 2.9 & 2.4 & 1.6 \\
$12-18^{\circ} \mathrm{C}$ & 1.4 & 2.0 & 3.9 & 3.8 & 3.1 & 2.3 & 2.5 \\
\hline
\end{tabular}




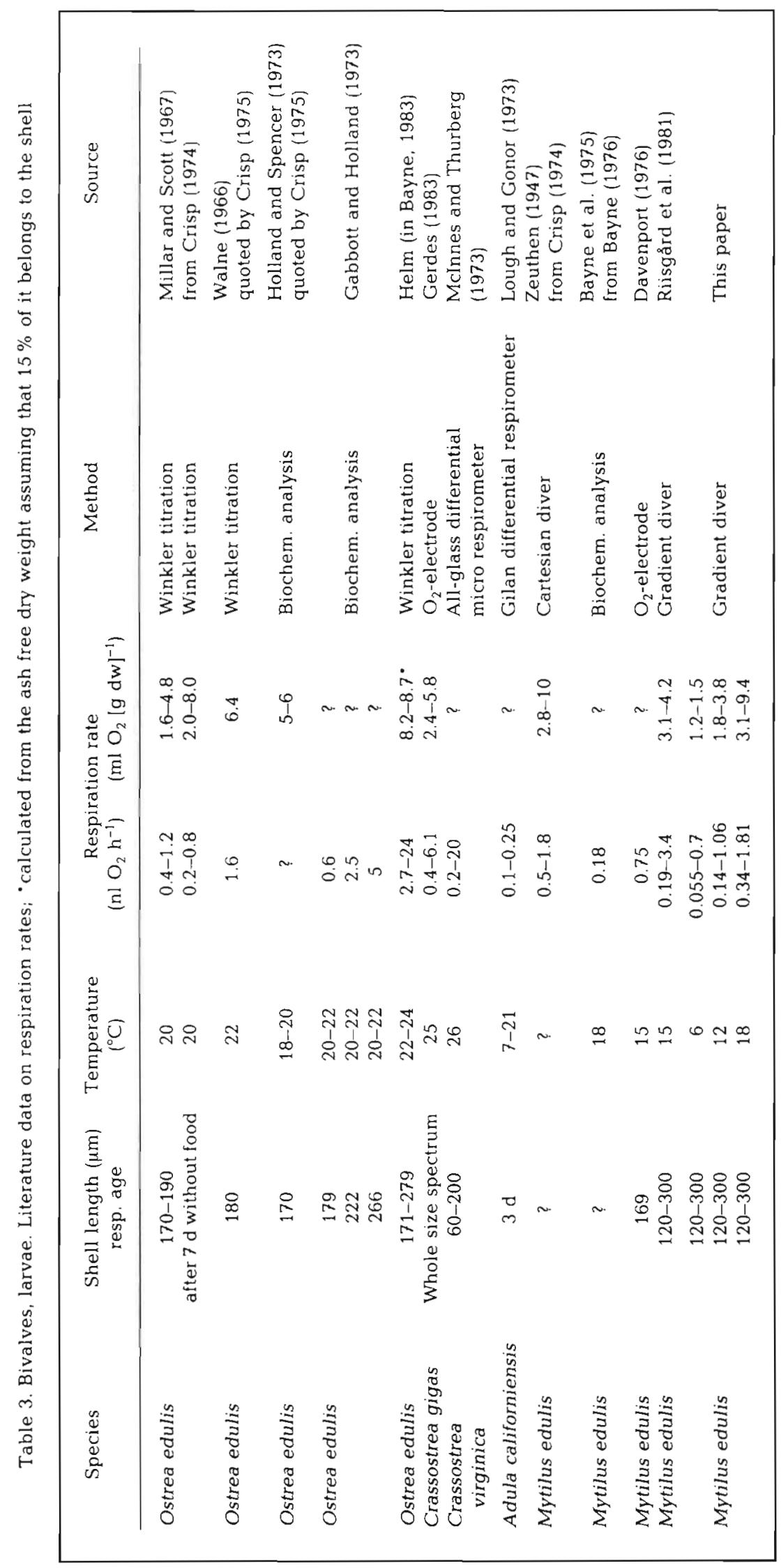


With adult mussels, Thompson and Bayne (1972) have observed a reduced metabolic activity below the normally maintained level during the process of starvation. This phenomenon must also be postulated for its larvae. As reported elsewhere (Sprung, 1984c) mussel larvae can survive under laboratory conditions without food for weeks or even months. In case they maintain their respiration level, it can be calculated that for most larval sizes tested its body mass must be respired down to less than $1 \%$. This is contrary to the visual impression the larvae give prior to death. Probably metabolism can be reduced drastically by ceasing to swim.

This calculation, however, ignores the fact that the substrate respired changes during the process of starvation. With planktonic organisms, mainly lipids are respired in short starvation periods of few days; in longer starvation periods proteins are used up, which form predominantly structural components (Holland, 1978). Starving bivalve larvae also show this mode as could be demonstrated by biochemical analysis (Millar and Scott, 1967; Holland and Spencer, 1973; Bayne et al., 1975).

Jørgensen $(1960,1962,1976)$ has pointed out that with suspension feeders, filtration and respiration rate are closely correlated. This must be so, because the respiration rate is an estimate of the energy loss of the animal and the filtration rate an important factor limiting energy uptake. Data for this relationship have been graphically represented in Fig. 5. Literature data for bivalve larvae reported previously are lower: 15 and $40 \mathrm{l}$ water filtered per $\mathrm{ml}$ oxygen consumed (oyster larvae; Jørgensen, 1962) and 16 to 261 water filtered per ml oxygen consumed (Mytilus larvae; Risgård et al., 1980).

\section{Respiration and body size}

In Fig. 6 data from Fig. 1 have been transformed to weight-specific respiration rates with data from Sprung (1984a). They confirm the general phenomenon that weight-specific respiration decreases with body size. For planktonic larvae, the value generally range between 1.6 and $10 \mathrm{ml} \mathrm{O}_{2} \mathrm{~h}^{-1}$ and g dry weight (Crisp, 1975; Holland, 1978). This is also confirmed here.

Consequently respiration can be related to body size by the allometric equation:

$$
\text { Respiration rate }=\mathrm{b} \times \text { body } \operatorname{size}^{\mathrm{m}}
$$

With weight data from Sprung (1984a) the exponents given in Table 4 can be calculated. For mussel larvae, Zeuthen $(1947,1953)$ quotes an exponent of 0.8 and Riisgård et al. (1981) of 0.90. Conover (1968, 1978) calculated for planktonic organisms a mean of 0.81

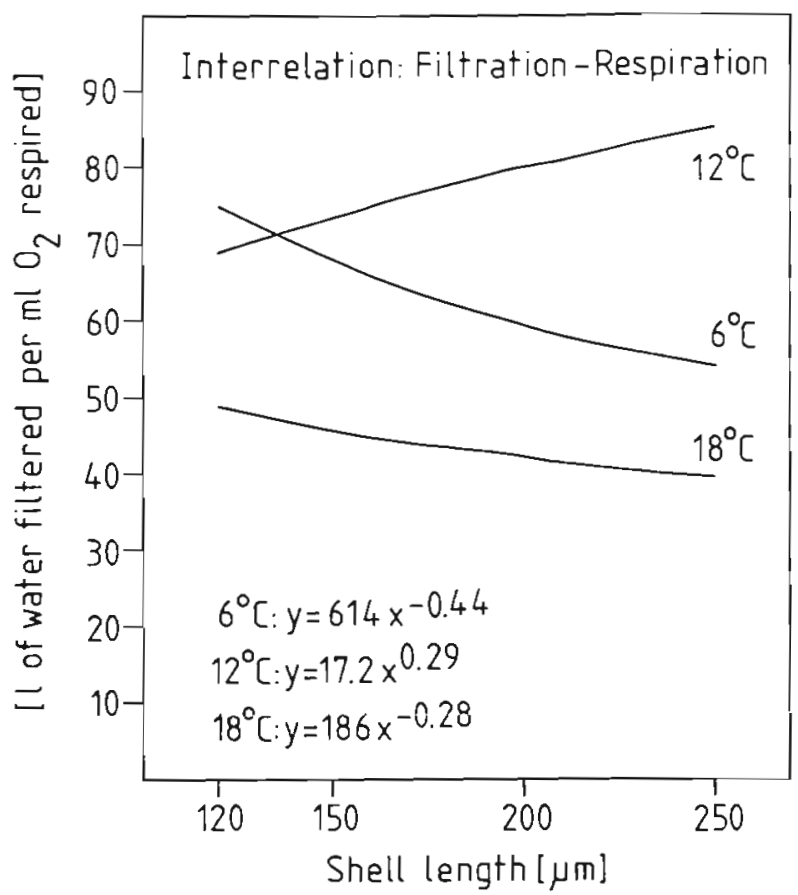

Fig. 5. Mytilus edulis, larvae. Intertelation between filtration and respiration rate; calculated with regression lines from Fig. 1 and Sprung (1984b); y: liter of water filtered per $\mathrm{ml} \mathrm{O}_{2}$ respired; $x$ : shell length $(\mu \mathrm{m})$

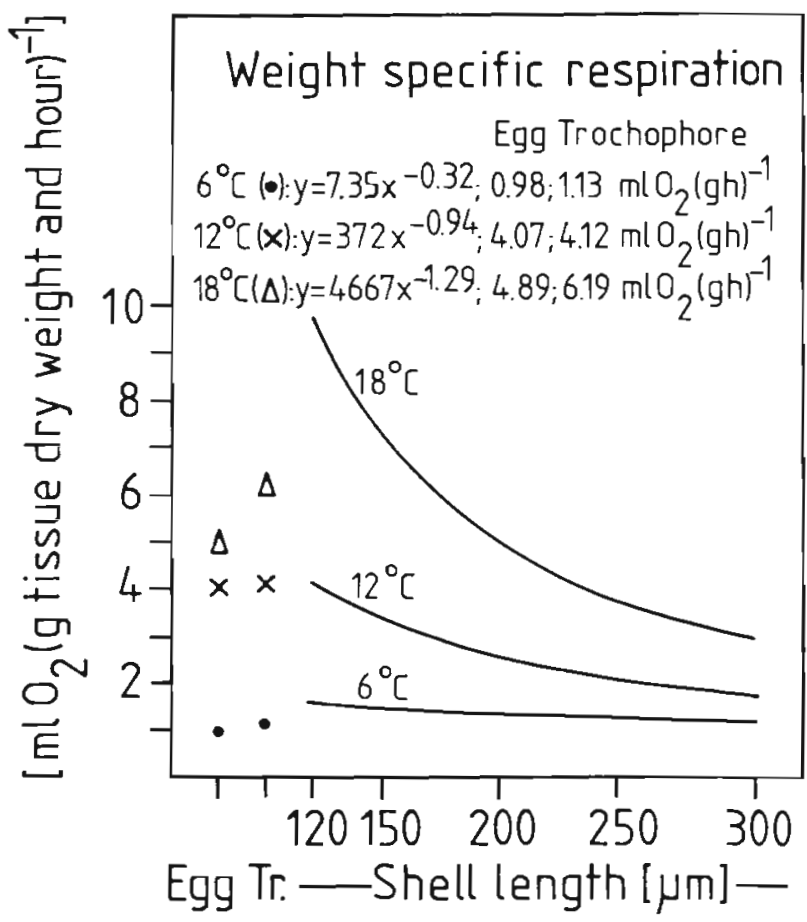

Fig. 6. Mytilus edulis, eggs and larvae. Weight specific respiration; calculated with data from Fig. 1 and Sprung (1984a); $\mathrm{y}$ : weight specific respiration $\left(\mathrm{ml} \mathrm{O}_{2}\right.$ lg tissue dry weight and hour $]^{-1}$; $x$ : shell length $(\mu \mathrm{m})$ 
Table 4. Mytilus edulis, larvae. Weight exponents (tissue dry weight) of the ingestion capacity, the filtration capacity and respiration rate; calculated with data from Fig. 1 and Sprung $(1984 a, b)$

\begin{tabular}{|llll|}
\cline { 2 - 4 } Temperature: & $6{ }^{\circ} \mathrm{C}$ & $12{ }^{\circ} \mathrm{C}$ & $18{ }^{\circ} \mathrm{C}$ \\
\hline Filtration capacity: & 0.75 & 0.79 & 0.50 \\
Ingestion capacity: & 0.65 & 0.84 & 1.04 \\
Respiration rate: & 0.90 & 0.70 & 0.59 \\
\hline
\end{tabular}

according to data of various authors. He believes that the exponent is independent of temperature. Although different exponents have been calculated for each temperature tested (Table 4 ), the results do not necessarily contradict this statement. The differences between 6 and $12^{\circ} \mathrm{C}$ as well as between 12 and $18^{\circ} \mathrm{C}$ are not significant. Probability that the exponents of the 6 and $18^{\circ} \mathrm{C}$ data are identical, however, is only $2.5 \%$ (calculated according to Sachs, 1978, p. 348).

During the whole process of growth, exponents $m$ of the respiration rate are expected to be higher than those of food uptake (Vahl, 1973; Winter, 1978). This can only be found with the $6^{\circ} \mathrm{C}$ values (Table 4). That this is not the case with the 12 and $18^{\circ} \mathrm{C}$ data may be attributed to the fact that the whole digestive system is still developing in small larvae. Although definite conclusions are very uncertain with this set of data, this would argue for a separate discussion of growth phenomena with the larvae apart from the adult mussels.

Acknowledgements. This paper is a contribution to research project 'Experimentelle Marine Ókosystemanalyse' sponsored by Bundesministerium für Forschung und Technologie, Bonn (Grant No. MFU-0328/1). It is based on parts of the author's doctoral thesis submitted to Kiel University. I am grateful to Professor Dr. W. Noodt for supervising the thesis, to Dr. K. Anger for helpful discussions of this paper, to Dr. E. Hagmeier for providing the algal cultures for the experiments, and to Dr. M. Rieper for correcting the manuscript. I am also indebted to Studienstiftung des Deutschen Volkes, Bonn-Bad Godesberg for financial support.

\section{LITERATURE CITED}

Bayne, B. L. (1964). The response of larvae of Mytilus edulis L. to light and to gravity. Oikos 15: 162-174

Bayne, B. L., Gabbott, P. A., Widdows, J. (1975). Some effects of stress in the adult on the eggs and larvae of Mytilus edulis L. J. mar. biol. Ass. U. K. 55: 675-689

Bayne, B. L. (1976). The biology of mussel larvae. In: Bayne, B. L. (ed.) Marine mussels: their ecology and physiology. Cambridge University Press, London, p. 81-120

Bayne, B. L., Scullard, C. (1977). An apparent specific dynamic action in Mytilus edulis L. J. mar. biol. Ass. U. K. 57: 371-378

Bayne, B. L. (1983), The physiological ecology of marine molluscan larvae. In: Verdonk, N. H., van den Biggelaar,
J. A. M., Tompa, A. (ed.) The Mollusca, Vol. III, Development. Academic Press, New York, p. 299-343

Conover, R. J. (1968). Zooplankton-life in a nutritionally dilute environment. Am. Zool. 8: 107-118

Conover, R. J. (1978). Transformation of organic matter. In: Kinne, O. (ed.) Marine ecology, Vol. IV, Dynamics. Wiley, Chichester, p. 221-499

Cragg, S. M., Gruffydd, L. D. (1975). The swimming behaviour and the pressure response of Ostrea edulis L veliconcha larvae. In: Barnes, $H$. (ed.) Proceedings of the 9th European Marine Biology Symposium. Aberdeen University Press, Aberdeen, p. 43-57

Cragg, S. M. (1980). Swimming behaviour of the larvae of Pecten maximus (L.) (Bivalvia). J. mar. biol. Ass. U. K. 60: $551-564$

Crisp, D. J. (1971). Energy flow measurements. In: Holme, N. A., McIntyre, A. D. (ed.) Methods for the study of marine benthos. Blackwell, Oxford, p. 197-279

Crisp, D. J. (1974). Energy relations of marine invertebrate larvae. Thalassia jugosl, 10: 103-120

Crisp, D. J. (1975). The role of the pelagic larva. In: Spencer Davies, P. (ed.) Perspectives in experimental biology, Vol. I. Pergamon Press, Oxford, p. 145-155

Davenport, J. (1976). A technique for the measurement of oxygen consumption in small aquatic organisms. Lab. Pract. 25: 693-695

Gabbott, P. A., Holland, D. L. (1973). Growth and metabolism of Ostrea edulis larvae. Nature, Lond. 241: 475-476

Gerdes, D. (1983). The Pacific oyster Crassostrea gigas. Part II. Oxygen consumption of larvae and adults. Aquaculture 31: $221-231$

Hidu, H., Haskin, H. H. (1978). Swimming speeds of oyster larvae Crassostrea virginica in different salinities and temperatures. Estuaries 1: 252-255

Holland, D. L., Spencer, B. E. (1973). Biochemical changes in fed and starved oysters, Ostrea edulis L., during larval development, metamorphosis and early spat growth. J. mar. biol. Ass. U. K. 53: 287-298

Holland, D. L. (1978). Lipid reserves and energy metabolism in the larvae of benthic marine invertebrates. In: Malins, D. C., Sargent, J. R. (ed.) Biochemical and biophysical perspectives in marine biology, Vol. IV. Academic Press, New York, p. 85-123

Hrs-Brenko, M., Calabrese, A. (1969). The combined effects of salinity and temperature on larvae of the mussel Mytilus edulis. Mar. Biol. 4: 224-226

Isham, L. B., Tierney, J. Q. (1953). Some aspects of the larval development and metamorphosis of Teredo (Lydrodus) pedicellata De Quatrefages. Bull. mar. Sci. Gulf Caribb. 2: $574-589$

Jørgensen, C. B. (1960). Efficiency of particle retention and rate of water transport in undisturbed lamellibranchs. J. Cons. perm. int. Explor. Mer 26: 94-116

Jørgensen, C. B. (1962). The food of filter feeding organisms. Rapp. P.-v. Réun. Cons. perm. int. Explor. Mer 153: 99-107

Jørgensen, C. B. (1976). Growth efficiencies and factors controlling size in some mytilid bivalves, especially Mytilus edulis L.: review and interpretation. Ophelia 15: 175-192

Klyashtorin, L. B., Yarzhombek, A. A. (1973). Energy consumption in active movements of planktonic organisms. Oceanology 13: 575-580

Konstantinova, M. I. (1966). Characteristics of the motion of pelagic larvae of marine invertebrates. Dokl. (Proc.) Acad. Sci. U. S. S. R. 170: 753-756

Lough, R. G., Gonor, J. J. (1973). A response-surface approach to the combined effects of temperature and salinity in the larval development of Adula californiensis (Pelecypoda: 
Mytilidae). II. Long-term larval survival and growth in relation to respiration. Mar. Biol. 22: 295-305

Lough, R. G. (1974). A re-evaluation of the combined effects of temperature and salinity on survival and growth of Mytilus edulis larvae using response surface techniques. Proc. natn. Shellfish. Ass. 64: 73-76

MacInnes, J. R., Thurberg, F. P. (1973). A new technique for measuring the oxygen consumption of larvae of the American oyster, Crassostrea virginica. Proc. natn. Shellfish. Ass. 63: 60-62

Mann, R., Wolf, C. C. (1983). Swimming behaviour of larvae of the ocean quahog Arctica islandica in response to pressure and temperature. Mar. Ecol. Prog. Ser. 13: $211-218$

Millar, R. H., Scott, J. M. (1967). The larva of the oyster Ostrea edulis during starvation. J. mar. biol. Ass. U. K. 47: $475-484$

Nexø, B. A., Hamburger, K., Zeuthen, E. (1972). Simplified microgasometry with gradient divers. C. r. Trav. Lab. Carlsberg 39: 33-63

Pechenik, J. A., Fisher, N. S. (1979). Feeding, assimilation, and growth of mud snail larvae, Nassarius obsoletus (Say), on three different algal diets. J. exp. mar. Biol. Ecol. 38: $57-80$

Riisgård, H. U., Randløv, A., Kristensen, P. S. (1980). Rates of water processing, oxygen consumption and efficiency of particle retention in veligers and young post-metamorphic Mytilus edulis. Ophelia 19:37-47

Riisgård, H. U., Randløø, A., Hamburger, K. (1981). Oxygen consumption and clearance in Mytilus edulis $\mathrm{L}$. veliger larvae of different size. Ophelia 20: 179-185

Sachs, L. (1978). Angewandte Statistik - Planung und Auswertung, Methoden und Modelle, 5th ed. Springer, Berlin

Sprung, M. (1980). Das Frühjahrswachstum der Miesmuschel (Mytilus edulis L.) bei kontinuierlicher und diskontinuierlicher Nahrungszufuhr im Freiland-Biotop und unter Laborbedingungen. Diplom-Arbeit, Universität Kiel

Sprung, M. (1984a). Physiological energetics of mussel larvae (Mytilus edulis). I. Shell growth and biomass. Mar. Ecol. Prog. Ser. 17: 283-293)

Sprung, M. (1984b). Physiological energetics of mussel larvae
(Mytilus edulis). II. Food uptake. Mar. Ecol. Prog. Ser. 17: 295-303

Sprung, M. (1984c). Experiments on nutritional stress on the larvae of the mussel Mytilus edulis L. In: Gray, J. S., Christiansen, M. E. (ed.) Eighteenth European Marine Biology Symposium, Oslo. Wiley, Chichester (in press)

Strathmann, R. R., Jahn, T. L., Fonseca, J. R. C. (1972). Suspension feeding by marine invertebrate larvae: clearance of particles by ciliated bands of a rotifer, pluteus, and trochophore. Biol. Bull. mar. biol. Lab., Woods Hole 142 505-519

Thompson, R. J., Bayne, B. L. (1972). Active metabolism associated with feeding in the mussel Mytilus edulis L. J. exp. mar. Biol. Ecol. 9: 111-124

Turner, H. J., George, C. J. (1955). Some aspects of the behaviour of the quahog, Venus mercenaria, during the early stages. In: Eighth report of investigations of the shellfisheries of Massachusetts. Department of Natural Resources, Division of Marine Fisheries, Commonwealth of Massachusetts, p. 5-14

Vahl, O. (1973). Pumping and oxygen consumption rates of Mytilus edulis L. of different sizes. Ophelia 12: 45-51

Vlymen, W. J. (1970). Enesgy expenditure of swimming copepods. Limnol. Oceanogr. 15: 348-356

Walne, P. R. (1966). Experiments on the large scale culture of the larvae of Ostrea edulis L. Fishery Invest., Lond. II, 25: $1-53$

Winter, J. E. (1978). A review on the knowledge of suspension-feeding in lamellibranchiate bivalves, with special reference to artificial aquaculture systems. Aquaculture 13: $1-33$

Wood, L., Hargis, W. J. (1971). Transport of bivalve larvae in a tidal estuary. In: Crisp, D. J. (ed.) Proceedings of the 4th European Marine Biology Symposium, Bangor. Cambridge University Press, London, p. 29-44

Zeiss, F. R. Jr. (1963). Effects of population densities on zooplankton respiration rates. Limnol. Oceanogr. 8: $110-115$

Zeuthen, E. (1947). Body size and metabolic rate in the animal kingdom with special regard to the marine microfauna. C. r. Trav. Lab. Carlsberg, Sér. chim. 26: 17-161

Zeuthen, E. (1953). Oxygen uptake as related to body size in organisms. Q. Rev. Biol. 28: 1-12

This paper was presented by Professor H.-P. Bulnheim; it was accepted for printing on March 16, 1984 